\title{
DAKWAH SUFISTIK DI ERA DIGITAL
}

\author{
Elmansyah
}

\begin{abstract}
ABSTRAK
Dakwah sufistik adalah dakwah yang dikaitkan istilah tasawuf, atau dakwah yang dilakukan oleh para pengamal tasawuf. Dakwah sufistik diakui berhasil dalam mengislamkan masyarakat nusantara, ketika mereka pada awalnya justru sudah beragama. Keberhasilan tersebut tidak lepas dari metode dan orientasi dakwah para sufi yang khas, yaitu hakikat dan makrifat. Kerinduan akan model dakwah semacam ini kembali muncul di era digital, di mana teknologi informasi kian canggih dan merata. Masyarakat digital menantikan dakwah sufistik di tengah-tengah kehausan mereka terhadap spiritual. Artikel ini mencoba memaparkan tentang dakwah sufistik di era digital, yang kian surut di permukaan, sebaliknya dakwah radikal semakin marak dan cenderung membahayakan umat Islam dari dalam. Kebutuhan akan dakwah sufistik di era ini, menjadi penting untuk segera dipenuhi, di tengah-tengah kehausan umat akan spiritualitas yang menentramkan. Tema sentral dalam artikel ini adalah pentingnya dakwah sufistik di era yang segala sesuatunya telah bersifat digital.
\end{abstract}

Kata Kunci: Dakwah, Sufistik, Digital

\section{A. Pendahuluan}

Akhir-akhir ini, sering kali nampak di mass media dan media sosial, bahwa Islam banyak ditampilkan dengan wajah yang "sangar", "saklek", dan penuh kebencian. Organisasi-organisasi Islam yang diharapkan mengayomi masyarakat, tidak jarang justru menunjukkan drama perbedaan yang membingungkan masyarakat. Dakwah
Islam dilakukan dengan cara yang "kurang" santun, sehingga melahirkan sikap kurang simpati dari masyarakat dunia yang non-Muslim, bahkan dari umat Islam itu sendiri.

Kenyataan bahwa setiap kasus kekerasan terjadi di berbagai tempat, selalu dihubungkan dengan Islam (M. Riza Sihbudi, 2007: 186) (kasus terorisme yang selalu dihubungkan dengan gerakan Islam Radikal). Setiap 
kali ada isu terkini, beberapa organisasi masayarakat Islam menaggapinya dengan tekstual-doktriner yang kaku (kasus dugaan penistaan agama dalam pilkada DKI). Setiap kali muncul pemberitaan, melahirkan kebencian (maraknya media propokasi di internet). Celakanya, fatwa-fatwa ulama yang keluar dari majelis, sering kali menghadirkan kontroversi (karena yang terkenal, acap kali fatwa yang bersifat multi tafsir). Akibatnya, wajah rahmatan lil 'alamin umat Islam semakin sulit untuk bisa disaksikan. Hal ini tentu saja mendatangkan kerugian tersendiri bagi umat Islam.

Kenyataan tersebut harus segera diatasi. Umat Islam harus kembali menampilkan wajah yang anggun di masyarakat, sebagaimana pernah ditampilkan oleh para da'i di era para Wali. Islam hadir di tengah-tengah masyarakat yang beragama, namun Islam dapat diterima, bahkan mereka yang telah beragama, justru berduyunduyun memeluk Islam. Tentu saja, dakwah para wali tidak dilakukan dengan cara yang kasar, keras dan penuh pemaksaan. Dakwah para wali dilakukan dengan santun, mengayomi dan mendamaikan. Menurut Alwi Shihab, karena mereka pada umumnya adalah para sufi yang senantiasa mengutamakan akhlak dan kebijaksanaan (Baca: Alwi Shihab, 1996: 8-12; Sofyan Rofi, 2016:2).

Artikel ini akan mencoba menjelaskan tentang pentingnya dakwah sufistik di era digital, suatu era di mana masyarakatnya telah "melek" teknologi transportasi dan informasi. Dakwah, di tengah-tengah masyarakat yang rasional, matematis dan dengan peralatan yang serba canggih. Gambaran mengenai praksis dakwah sufistik yang dapat diterapkan dalam konteks masyarakat digital, akan diuraikan di sini sebagai pilihan alternatif.

\section{B. Dakwah Sufistik di Era Digital}

\section{Hakikat Dakwah}

Dakwah adalah aktifitas mengajak, memanggil, atau menyeru orang lain agar melakukan apa yang menjadi tujuan dari si penyeru/pemanggil/pengajaknya. Kata ini berasal dari bahasa Arab, yakni: da'a - yad'u, yang merupakan isim mashdar (kata benda bentukan) dari kata fiil tersebut. Dalam bahasa lain (Kristen dan Yahudi) disebut misi atau zending (Joko Tri Haryanto, 2014: 271). 
Istilah Dakwah banyak sekali ditemukan dalam al-Qur'an. Ada sebanyak 198 kali disebutkan dalam bentuk peran dan fungsi masing masing: Pertama, Dakwah dalam arti Ajakan. Allah SWT dalam al-Qur'an memerintahkan untuk mengajak, sebagaimana termaktub dalam Q.S. AlNahl ayat 125. Ajakan itu disesuaikan dengan orang yang diajak, dan paling tidak ada 3 (tiga) metode mengajak dalam ayat ini, yaitu: dengan hikmah, dengan berdepat, dan dengan contoh yang baik. Kedua, Dakwah dalam arti Doa. Hal ini merujuk kepada kisah Nabi Nuh, yang berdakwah dengan cara Berdoa kepada Allah SWT. Ketika itu, Nabi Nuh AS memohon kepada Allah SWT: “Wahai Tuhanku, penjara lebih aku sukai daripada memenuhi ajakan mereka kepadaku. Dan jika tidak Engkau hindarkan aku dari tipu daya mereka, tentu aku akan cenderung untuk [memenuhi keinginan mereka], dan tentulah aku termasuk orang-orang yang bodoh" (Q.S.Yusuf [12]:33). Ketiga, Dakwah dalam arti Tuduhan. Dalam kasus dunia hukum, sering kali terdengar kata "dakwaan" bagi orang yang dituduh melakukan tindakan melanggar hukum.

Selain itu, dalam Al-Qur'an juga dijelaskan mengenai kata dakwah sebagai bentuk: Aduan atau memanggil seseorang untuk menyampaikan keluh dan kesahnya; Permintaan; Mengundang, merujuk pada malaikat Israfil yang mengundang manusia untuk berkumpul di Padang Mahsyar; dan, Sebutan yang digunakan untuk memanggil seseorang bukan berarti anak kandung sendiri. (Tim penyusun, dalam: http://www.eurekapendidikan. com /2015/11/pengertian-dakwah-dalampandangan-huk um.html).

Dakwah, dapat berkonotasi positif dan dapat pula berkonotasi negatif. Dakwah dalam konotasi negatif, berarti menyerukan untuk berbuat munkar, mencelakai orang lain atau merusak alam semesta. Sedangkan berdakwah dalam konotasi positif berarti menyampaikan sesuatu kepada orang lain yang besifat mengajak untuk merubah suatu keadaan yang tidak baik kepada yang baik dan terpuji (Nur Ahmad, 2014: 324).

Dakwah merupakan kegiatan umat Islam yang didasari pada Iman dan kesadaran untuk mengaktualisasikannya di masyarakat. Umat Islam diwajibkan untuk berdakwah (menyampaikan risalah meskipun hanya satu ayat). Hakikat 
dakwah adalah aktualisasi imani yang dimanifestasikan dalam suatu sistem kegiatan manusia beriman, dalam bidang kemasyarakatan secara teratur, mempengaruhi cara merasa, berfikir, bersikap, dan bertindak manusia pada dataran kenyataan individual serta sosiokultural. Kegiatan ini dilakukan dalam rangka mewujudkan ajaran Islam dalam segala segi kehidupan manusia dengan menggunakan cara-cara tertentu (Hafidhuddin; Sasono; Saefuddin, 1998: 177).

Melalui uraian di atas, dapat dikatakan bahwa dakwah merupakan kewajiban umat Islam sebagai hamba, sekaligus sebagai khalifah. Mengajak orang lain agar melakukan tindakantindakan positif dan kembali kepada fitrahnya, merupakan upaya untuk mewujudkan kebajikan di alam semesta, sebagai khalifah di muka bumi. Berdo'a, memohon kepada Allah SWT untuk setiap apa yang diinginkan, merupakan bagian dari kewajiban seorang hamba. Melakukan dan mewujudkan keadilan di muka bumi, merupakan bagian dari upaya menjalankan perintah Allah dan menjauhi larangan-Nya. Dengan demikian, maka hakikat dakwah adalah manifestasi dari Iman, Islam dan Ihsan.

\section{Dakwah Sufistik}

Istilah sufistik terambil dari kata sufi atau tasawuf. Dakwah sufistik yang dimaksud di sini adalah dakwah yang mirip dengan apa yang dilakukan oleh para sufi. Dakwah semacam ini diyakini lebih berhasil dari pada dakwah dengan cara-cara yang lain.

Secara etimologi kata tasawuf dapat dilihat dari beberapa pengertian: Pertama, tasawuf berasal dari istilah yang dikionotasikan dengan Ahlu alSuffah, yang berarti sekelompok orang pada masa Rasullullah SAW, yang hidup di serambi-serambi masjid Nabawi, mereka mengabdikan hidupnya untuk beribadah kepada Allah SWT. Kedua, tasawuf berasal dari kata shafa, yang berarti sebutan bagi orang-orang yang "bersih " atau "suci", atau orang-orang yang menyucikan dirinya di hadapan Tuhan-Nya. Ketiga, tasawuf berarti dari kata shaf, yang dinisbahkan kepada orang-orang yang ketika shalat selalu berada di shaf yang paling depan. Keempat, tasawuf dinisbahkan kepada orang-orang dari Bani Shufah, yang sudah ada sejak Rasulullah SAW belum diangkat sebagai Rasul. Mereka ini 
adalah orang-orang yang mengabdikan dirinya untuk keperluan Ka'bah. Kelima, tasawuf dinisbahkan dengan kata istilah Yunani, yaitu Sovia, yang berarti filsafat atau kebijaksanaan (Muhammad Ghalab, tt: 26-27). Keenam, Tasawuf berasal dari kata Shauffanah, sebangsa buah-buahan kecil dan banyak tumbuh di padang pasir di tanah arab. Ini dilihat dari pakaian kaum sufi yang berbulubulu, seperti buah itu pula, sebagai simbol kesederhanaannya (Barmawie Umarie, 1996: 9). Ketujuh, tasawuf berasal dari kata Shuf yang berarti bulu domba atau wol (Athoullah Ahmad, 1985: 96).

Jika dilihat dari istilah-istilah asal tersebut di atas, maka bagian ketujuh lebih mewakili apa yang disebut dengan tasawuf. Dalam hal ini, para ahli memang berbeda pendapat, namun cenderung sepakat pada istilah shuf sebagai asal kata tasawuf. Barmawie Umarie, misalnya mengatakan bahwa terma-terma tersebut hingga saat ini belum ada yang menggoyahkan pendapat bahwa tasawuf itu berasal dari wazan (timbangan) tafa'ul, yaitu tafa'alayatafa' 'alu-tafa'ulan dengan mauzun, yaitu tashawwafa-yatashawwafu- tashawwufan (Barmawie Umarie, 1996: 9).

Melalui istilah tasawuf itulah, muncul kata sufi, sebagai sebutan bagi orang yang hidup dalam ketasawufan. Kemudian, kata sufistik diambil dari kata sufi, yang berarti mirip dengan para sufi. Dengan demikian dakwah sufistik di sini dapat dimaknai sebagai dakwah yang dilakukan dengan cara yang sama atau mirip dengan para sufi.

Dakwah sufistik, tidak lepas dari konsep dakwah yang dilakukan oleh Rasulullah SAW sebagai teladan. Aktifitas dakwah telah dimulai dan dicontohkan oleh Rasulullah SAW. Beliau telah memberikan contoh dakwah yang baik dan benar, seperti: 1) menyampaikan kebenaran kepada keluarga dan orang-orang terdekatnya (bi al-Lisan); 2) mengajarkan tauhid dan kehidupan kepada umatnya (bi alKalam); 3) memberikan contoh perilaku (akhlak) yang mulia (bi al-Hal); dan, 4) mengirimkan surat kepada para musuh dan sahabatnya (bi al-Qalam). Semua itu tergantung kepada Mad'u (objek dakwah)-nya. Kegiatan ini dilanjutkan oleh pada sahabat penerusnya, hingga oleh para ulama mutaakhirin. Dakwah 
dikembangkan sesuai dengan perubahan zaman.

Aktifitas dakwah semacam ini juga terjadi di Indonesia, terutama pada awal-awal penyebaran Islam di Nusantara. Para da'i menjalankan aktifitas dakwah secara kreatif di tengahtengah umat yang sudah beragama (Hindu dan Budha). Sebut saja awal terciptanya kegiatan Tahlilan di masyarakat. Konon kegiatan ini merupakan kreatifitas para da'i di masa awal-awal penyebaran Islam. Para da'i melihat kecendrungan masyarakat dalam pemujaan, dengan kalimat-kalimat mistik yang aneh. Kemudian para da'i menyusun ayat-ayat kunci yang dibaca dengan bersama-sama, kemudian diakhiri dengan bacaan Laa ilaaha illa Allah. Ada juga yang mirip dengan pemujaan, seperti kata Allah, Allah, Allah secara berirama. Ada pula yang mengambil suku kata terakhirnya saja, seperti: $H u, H u, H u \ldots$, dan seterusnya. Sehingga, kegiatan ini menarik dan masyarakat yang beragama, menjadi terbiasa dengan kegiatan tersebut. Kemudian, adanya peringatan 3 (tiga) hari, 7 (tujuh) hari, 40 (empat puluh) hari, hingga 1000 (seribu) hari pasca kematian, adalah upaya para da'i dalam menarik minat masyarakat. Selain itu, adanya simbol-simbol berupa makanan yang dikaitkan dengan rukun Islam, semisal: satu sisir (setangkep: Jawa) pisang, dimaknai sebagai simbol dua kalimah syahadat, yang tidak terpisahkan satu sama lain. Nasi yang dibentuk gunungan menjulang ke langit, sebagai simbol kebersihan hati menuju Tuhan. Sayur mayor yang disusun rapi di sekeliling gunungan, sebagai simbol ibadah sunnah. Daging ayam (Ingkung: Jawa) yang dibagi kecil-kecil agar rata pembagiannya, sebagai simbol zakat, dan seterusnya dalam ritual kenduri. Tentu saja hal ini tidak ada dalam ajaran Islam Syari'at, namun para da'i lebih mengutamakan hakikat.

Para sufi dalam berdakwah di Indonesia, sangat mempertimbangkan aspek-aspek lingkungannya, baik itu suasana politik, kondisi psikologis, adat istiadat, tradisi dan kecenderungan masyarakat ketika itu. Media dakwah yang digunakan juga bervariasi, seperti melalui gerakan tarekat, politik, seni dan budaya, seperti yang dilakukan oleh para Walisongo yang menjadi penghulu agama di kerajaan Demak dan awal kerajaan Mataram. Tarekat yang dari asalnya di Timur Tengah, memiliki tradisi 
Khanqah, Ribath, dan Zawiyah sebagai pusat-pusat pendidikan tasawuf, di Indonesia dikembangkan dalam bentuk pesantren-pesantren yang merupakan perpaduan dari pola pendidikan HinduBudha dengan tradisi tasawuf (Joko Tri Haryanto, 2014: 281).

Kreatifitas para da'i dalam menyampaikan risalah-Nya, benar-benar menyentuh sanubari masyarakat, ketika sampai pada persoalan seni. Wayang adalah salah satunya. Para da'i, seperti Sunan Sunan Kalijaga, dikenal sebagai da'i yang banyak berdakwah melalui seni wayang (Hery D. Kurniawan, 2003: 26). Wayang, dalam kacamata orang awam merupakan patung yang dimainkan. Tak pelak lagi, apa yang dilakukan oleh para da'i ketika itu, merupakan terobosan dakwah yang luar biasa, meski dalam perspektif syari'at, akan sangat bertentangan. Namun, itulah kreatifitas yang patut untuk dijadikan sebagai contoh para da'i di masa kini.

Belum lagi jika dilihat dari pergerakan para sufi dalam melawan penjajah. Peperangan yang terjadi di Cilegon Banten yang dimotori pengamal Tariqoh Qadiriyah. Juga perlawanan Singaparna di bawah pimpinan K.H. Zarnal Musthafa. Perlawanan di
Paterongan oleh K.H. Romli, seorang Musrsyid Toriqah, dan tidak kalah pentingnya adalah apa yang dilakukan oleh Syech Yusuf al-Makassari baik di Banten maupun di Afrika Selatan. Semua itu merupakan kreatifitas dakwah yang patut dibanggakan (H.A. Khotimi Bahri, dalam: http://www.muslimoderat. com /2015/12/dakwah-santun-ala-sufimengenal-islam.html\#ixzz4NsBAyvZv.

Apa yang dilakukan oleh para wali, tokoh-tokoh tarekat di masa lalu, semuanya merupakan kegiatan dakwah. Dakwah yang mereka lakukan terbukti berhasil memikat hati masyarakat, sehingga umat Islam kian hari-kian bertambah. Dakwah yang seperti inilah yang diharapkan terjadi di era sekarang ini, era yang dikenal sebagai era digital. dakwah yang mengedepankan hakikat dan makrifat.

Hakikat berasal dari bahasa arab yang mempunyai arti "Haq" atau kebenaran (Moch. Siddiq, 2001: 7). Hakikat merupakan penyaksian manusia tentang rahasia-rahasia ketuhanan dengan mata hatinya (M. Toriquddin, 2008: 107). Hakikat juga berarti menyelami dan mendalami apa yang tersirat dan tersurat dalam syari'at, sebagai tugas menjalankan Firman Allah (Toriquddin, 2008: 99). 
Mengedepankan

hakikat

bermakna bahwa para sufi lebih menekankan pada kebenaran yang muncul dari mata hati, sebagai upaya untuk mendalami apa yang tersirat dan tersurat dalam syari'at, sebagai langkah dalam menjalankan apa yang difirmankan oleh Allah SWT. Itulah sebabnya, para sufi membagi hal-hal yang baru dalam agama menjadi dua, yakni bid'ah hasanah (bid'ah yang baik) dan bid'ah sayyi'ah (bis'ah yang buruk).

Sementara makrifat secara bahasa Ma'rifat berasal dari kata arafa, ya'rifu, irfan, ma'rifatan, yang artinya pengetahuan atau pengalaman. Ma'rifah adalah pengetahuan yang obyeknya bukan pada hal-hal yang bersifat zahir, tetapi lebih mendalam terhadap batinnya dengan mengetahui rahasianya. Dalam tasawuf, Ma'rifat diartikan sebagai pengetahuan mengenai Tuhan melalui hati sanubari. Pengetahuan itu demikian lengkap dan jelas, sehingga jiwanya merasa satu dengan yang diketahuinya itu, yaitu Tuhan (Abudin Nata, 2012: 219-220). Menurut Hamka, ma'rifat adalah kumpulan dari ilmu pengetahuan, perasaan, pengalaman, amal dan ibadah (Moch. Siddiq, 2001: 11).
Mengedepankan makrifat berarti mengedepankan hati sanubari dalam mengungkap dan mewujudkan kebenaran dakwah. Para sufi mengutamakan ilmu pengetahuan, perasaan, pengalaman, amal dan ibadah dalam berdakwah. Mereka tidak mengutamakan hukum-hukum yang mengikat terlebih dahulu, melainkan menyentuh hati masyarakat agar mereka memahami makna terdalam dari Islam, Iman dan Ihsan. Karenanya, dakwah sufistik lebih bisa diterima oleh masyarakat, baik awam maupun kaum intelektual.

\section{Era Digital}

Secara bahasa, era digital berasal dari dua buah kata, yaitu "era" dan "digital". Era digital adalah suatu era di mana segala sesuatunya disandarkan pada semua yang bersifat "digit", deret angka. Era ini berawal dari ditemukannya sifat angka yang mampu berperan sebagai simbol pembuatan alat-alat canggih, pasca modernisasi besar-besaran terjadi di berbagai belahan dunia, terutama di Barat. Mereka menggunakan simbol angka Nol (0) dan Satu (1), untuk menyebutkan 
kerja "Off" dan "On", pada perangkat yang diciptakan. Ini merupakan prinsip kerja "Mematikan" yang satu, "Menghidupkan" yang lain secara bergantian. Semakin cepat sistem ini bekerja, maka semakin canggih alat yang dihasilkan. Mereka menyebutnya dengan istilah "Bit" (Binary Digit). Dalam Wikipedia berbahasa Indonesia, dijelaskan bahwa istilah "Digital" berasal dari bahasa Yunani, "Digitus" yang artinya jari-jemari. Jumlahnya yang normal ada 10 (sepuluh). Hitungan angka sepuluh terdiri dari dua radix, yaitu 1 dan 0 . Bilangan ini disebut sebagai bilangan biner (1 dan 0). ( Lihat: Wikipedia berbahasa Indonesia, dalam: https://id.wikipedia.org/wiki/Digital. diakses pada Kamis, 25 Februari 2016).

Dalam kamus Oxford Advanced Learner's Dictionary, ditemukan kata "era" yang dimaknai sebagai a period in history starting from a particular time or event or having particular characteristic (suatu periode/masa dalam sejarah yang dimulai pada waktu tertentu atau kejadian tertentu atau memiliki karakter/sifat tertentu) (A S. Hornby, 1995: 389). Sedangkan kata "digital" berasal dari kata "digit", yang artinya any of the ten numbers from 0 to 9 (angka berapa saja dari sepuluh angka, yaitu dari angka 0 sampai angka 9); dapat juga dimaknai sebagai kata sifat yang berarti showing amounts by means of numbers (yang dinisbatkan kepada jumlah bilangan tertentu); of fingers, thumb or toe (atau yang dinisbatkan pada jari-jari tangan, jempol atau jari-jari kaki) ((As. Horby, 1995: 323).

Melalui prinsip digital, berbagai alat super canggih terus berkembang di masyarakat, seperti kamera, televisi, komputer, telepon genggam, dan lain sebagainya. Inovasi-inovasi demikian cepat terjadi, semakin hari semakin canggih perangkat yang tercipta. Sehingga tanpa disadari, perannya menjadi sangat vital. Tanpa kehadiran perangkat tersebut, manusia seolah lumpuh, buta dan tuli. Bayangkan, sehari saja tanpa telepon genggam, bagaikan manusia yang tersesat di tengah hutan yang lebat, tanpa tahu jalan keluar!

Secara istilah Era digital dimaknai sebagai suatu masa di mana sebagian besar masyarakat menggunakan sistem digital dalam kehidupan sehari-harinya (Irwansyah, "Masa Digital di Indonesia", dalam: Institut Komunikasi Indoesia Baru: http://komunikasi.us/index.php/ course/15-komunikasi-teknologi-dan- 
masyarakat/2135-masa-digital-diindonesia. Diakses pada Kamis, 25 Februari 2016.).

Alat-alat yang menggunakan sistem digital, mengisi setiap relung kehidupan umat manusia di dunia, tanpa terkecuali. Perangkat sistem digital membentuk dunia tersendiri, yaitu dunia digital. Dunia digital adalah dunia yang sangat besar, rumit, dan eksplosif. Dunia ini berisi keajaiban dan kengerian, serta segala sesuatu di antaranya (Admin, "Pemimpin Kristen dalam Era Digital", dalam: http://lead.sabda.org /pemimpin kristen_dalam_era_digital. Diakses pada Kamis, 25 Februari 2016).

Saat ini kita telah berada di dunia digital, dunia yang merupakan puncak keberhasilan abad modern, yang bertolak dari paham nihilisme. Paham yang menganggap pada Tuhan telah mati, tiada. Paham titik balik dari dominasi gereja yang memasung kreatifitas umatnya, menjadi keluar sebagai manusia bebas nilai, namun mampu melahirkan kemudahankemudahan bagi umat manusia. kemudahan-kemudahan itu ditandai dengan munculnya alat-alat canggih yang sangat membantu bagi aktiftas manusia di muka bumi. Akan tetapi yang perlu dipahami oleh umat Islam, adalah bahwa konsep digital pada dasarnya justru berasal dari umat Islam itu sendiri, yaitu: Laa ilaaha illa Allah.

\section{Metode Dakwah Sufistik}

Menurut teori A.H. Johns, para da'i yang menyebarkan agama Islam di Nusantara adalah para sufi. Mereka berhasil melakukan penyiaran Islam dan mengislamkan sejumlah besar penduduk Nusantara sejak abad ke-13. Keberhasilan itu didukung oleh faktor kemampuan kaum sufi dalam menyajikan Islam secara atraktif (Azyumardi Azra, 1998: 24). Selain itu, metode yang digunakan sesuai dengan tuntutan masyarakat pada saat itu.

Metode dakwah dimaknai
sebagai ilmu pengetahuan yang
mempelajari cara-cara melakukan dakwah, demi mencapai tujuan dakwah yang efektif dan efesien, atau cara mencapai tujuan dakwah (Jalaluddin Rakhmad, 1999: 160). Para Sufi dalam dakwahnya, selalu menekankan pengetahun dan akhlak mulia. Misi utama seorang da'i adalah menyempurnakan akhlak mad'u-nya. Pola yang dibangun pada dakwah sufistik lebih menekankan pada tarbiyah 
dan ta'lim (pendidikan dan pengajaran) dengan materi dan pelatihan yang berjenjang secara berkesinambungan. Tujuan dakwah sufistik bukan sekedar menyampaikan risalah, namun sampai pada implementasi dalam segala lini kehidupan. Oleh karena itu metode dakwah sufistik adalah holistik dan eksklusif (Siti Zainab, 2008: 21).

Holistik, artinya dakwah sufistik bersifat menyeluruh, mencapai semua aspek kehidupan, baik dunia maupun akhirat. Hal ini dapat dilihat dari perhatian seorang syeikh (Mursyid) kepada murid-nya ketika datang. Umumnya para Mursyid akan mempertanyakan keluarga, usaha dan lain sebagainya yang terkait dengan si Murid. Pada tarekat tertentu, seorang Mursyid akan mengajari bagaimana berdagang, bertani dan seterusnya, yang sesuai dengan tuntunan syari'at dan tarekat. Kemudian, dikatakan eksklusif karena dakwah bersifat tertutup. Ada syarat yang harus dipenuhi, salah satunya adalah bai'at. Setelah seseorang berbai'at kepada Mursyid tertentu, barulah ajaran dan perhaian itu diberikan.

Imam Al-Ghazali melibatkan beberapa unsur-unsur dakwah, meliputi: a) Da'i (Muhtasib). Seorang da'i adalah komunikator, sebagai penyampai pesan dakwah. Karenanya, seorang da'i (secara umum) dalam melaksanakan tugasnya memiliki syarat-syarat sebagai berikut: 1) Orang mukallaf muslim dan orang yang sanggup; 2) Islam, karena ia membela Islam; 3) Adil, seorang da'i harus bisa bersikap adil terutama dalam menyelesaikan suatu perselisihan; 4) Beriman; 4) Shaleh; 5) Mengetahui tempat-tempat dakwah, batas-batasnya, jalan-jalannya, dan penghalangpenghalangnya agar ia dapat membatasi padanya, sesuai dengan batas agama; 6) Menjauhi diri dari dosa-dosa; dan, 7) Memiliki budi pekerti, lemah lembut dan kasih sayang serta sabar dalam menjalankan dakwahnya (Miftahul Munif, dalam: http://www.nusudan.com/2012/ 02/konsep-dakwah-sufi-relevansinyadiera.html).

Para sufi terkenal sangat kreatif dalam menggunakan media dakwah karena kebanyakan para sufi berpahaman bahwasanya tidak semua yang baru itu merupakan bid'ah atau hal yang dilarang oleh agama, tetapi mereka lebih membagi bid'ah menjadi dua: bid'ah hasanah atau lebih layak dikatakan sunah hasah dan bid'ah dhalalah. Ada beberapa media atau sarana yang digunakan para sufi dalam 
berdakwah diantaranya adalah: Halaqatul zikir (majlis zikir), Khalwahkhalwah Al-qur'an, Masjid, Zawiyah sufiyah, Tulisan, dan di era sekarang ini, para sufi telah mulai menggunakan Media internet. Sekarang banyak kita temukan situs-situs sufi dari berbagai Negara, contoh kecil di Indonesia ada situs www.sufinews.com. (Miftahul Munif, dalam: http://www.nusudan. com/2012/ 02/konsep-dakwah-sufi-relevansinyadiera.html).

Kreatifitas para sufi memang tidak diragukan lagi dalam berdakwah. Itulah sebabnya, metode-metode mereka banyak dikembangkan oleh para da'i nusantara akhir-akhir ini, dan dinilai sukses di mata masyarakat umum. Misalnya KH. Abdullah Gymnastiar dengan dakwah lemah lembutnya, Ustadz Arifin Ilham dengan dakwah zikirnya, Ary Ginanjar Agustian dengan teori kesuksesannya, dan masih banyak lagi para da'i yang meminjam teori-teori dakwah para sufi terdahulu. Dakwah semacam inilah yang belakangan ini semakin meredup, dan digantikan dengan dakwah yang cenderung radikal.

\section{Dakwah di Era Digital}

Sadar atau tidak, bagaimana pun juga saat ini kita sudah berada di dunia digital. Generasi kita hari ini adalah generasi digital. Mereka tumbuh bersama perangkat teknologi digital. Kehidupan sehari-hari mereka lekat dengan internet serta teknologi informasi lainnya. Mereka aktif berkomunikasi dan berinteraksi melalui media sosial dan memanfaatkan fasilitas yang tersedia di sana (Admin, "Peran Orang Tua di Era Digital", dalam: http://www.dakwatuna. com/2014/10/27/58969/peran-orang-tuadi-era-digital/ \#ixzz41BKP65Iv).

Beradasarkan uraian di atas, dapat kita simpulkan bahwa era digital dapat dimaknai sebagai suatu masa di mana prinsip-prinsip digital menjadi mutlak dipegang dan diaplikasikan dalam semua lini kehidupan. Kemajuan teknologi dan informasi di Era digital, memang tidak dapat dimungkiri telah membawa manfaat yang luar biasa di kalangan umat manusia. Kemudahan dan kecepatan akses informasi, menciptakan kenyamanan dan kesenangan tersendiri dalam berkomunikasi dan berinteraksi antar sesama.

Namun, bagaimana pun juga kemajuan teknologi informasi telah 
banyak membawa kerusakan moral bagi masyarakat dunia. Semuanya tergantung pada manusianya itu sendiri (Man Behind the Gun). Bagi orang yang pandai dan bijak, kemajuan teknologi informasi akan dijadikan sebagai alat untuk hal-hal yang positif, dan sebaliknya bagi mereka yang tidak bertanggung jawab, maka kemajuan ini justru akan melahirkan masalah-masalah baru yang terkadang menabrak aspekaspek moralitas yang selama ini dijaga dan dihormati oleh masyarakat. Masalah-masalah itu antara lain: Pornografi, perjudian, prostitusi online, sikap ingin serba instan dari anak-anak, dan autisme sosial akibat terlalu asyik bermain game dan lain-lain. Hal ini tentu saja menjadi bagian dari ancaman moralitas yang sangat berbahaya bagi generasi muda (Uswadin, 2013).

Menurut Ary Ginanjar Agustian, sebagaimana dikutip oleh Ahmad Taufik Nasution, "Jika manusia tidak mengikutinya dengan prinsip bilangan biner, maka manusia akan menjadi budak dari peranti digital tersebut" (Ahmad Taufik Nasution, 2009: 200). Prinsip bilangan biner yang dimaksud adalah prinsip Laa Ilaaha IIla Allah. Laa llaaha (tidak ada Tuhan) merupakan angka 0 (Nol), Illa Allah (kecuali Allah), disimbolkan dengan angka 1 (satu). Satu artinya hanya Allah yang berhak kita sembah dan Nol artinya tidak tuhan selain Allah (Ridwan Mukri, 2009: 75).

Lebih lanjut, menurut Ahmad Taufik Nasution, manusia digital cenderung meninggalkan jati dirinya sebagai ciptaan Tuhan, kemudian berlari mencari tuhan-tuhan lainnya yang bersifat artificial, seperti cyberpace, kapitalisme, liberalisme, dan lain-lain pasca modernism. Teknologi dijadikan sebagai tujuan (ends), bukan sebagai alat, sehingga manusia menuhankan dirinya, karena merasa hebat (Ahmad Taufik Nasution, 2009: 203).

Era memang sudah berubah, dari era keterbelakangan akibat penjajahan fisik menjadi era penjajahan psikis. Perang opini di era digital, jauh lebih berat jika dibandingkan dengan perang angkat senjata di masa silam. Perang opini membutuhkan strategi dan kemampuan intelektual, serta keahlian digital. Masyarakat digital hanya percaya pada fakta yang didukung oleh datadata, dan argumentasi rasional. Di sisi lain, figur percontohan para ulama juga dipertaruhkan. 
Dakwah di era digital diakui sangat membuka peluang yang lebih efektif. Sebagaimana dilansir oleh laman ChaneIMuslim.com, bahwa data yang dihimpun berdasarkan hasil survei indikator Teknologi Informasi dan Komunikasi (TIK) yang dirilis Badan Litbang Kominfo RI (2015), menunjukkan bahwa keluarga pengakses TIK di Indonesia tergolong tinggi. Akses rumah tangga Indonesia tertinggi adalah akses terhadap televisi sebanyak 86,7 persen, disusul pengakses melalui handphone sebanyak 84,3 persen, kemudian radio sebanyak 37,5 persen, dan internet sebesar 35,1 persen. Selain peluang, tantangan dakwah di era teknologi digital juga tak kalah beratnya. Sebut saja pornografi yang tak kalah penetrasinya di jagat maya. Bayangkan, industri pornografi itu nilainya Rp 400 triliun. Ini tantangan serius yang harus dihadapi oleh para da'i dewasa ini (https://www.chanelmuslim.com/berita/er a-digital-membuka-peluang-dakwahyang-lebih-efektif/32797/).

Saat ini umat Islam tengah menghadapi suatu kenyataan bahwa ia berada pada keterbelakangan peran dalam percaturan dunia. Umat Islam senantiasa menjadi objek (jika tidak ingin disebut 'bulan-bulanan' umat lainnya), di mata masyarakat internasional. Citranya sangat ditentukan oleh opini masyarakat non-muslim (Didin Hafiduddin, 1998: 86). Oleh karena itu, dibutuhkan upaya serius dalam menggarap aksi dakwah yang dapat mengangkat harkat dan martabat umat Islam itu sendiri di mata dunia. Namun persoalan yang sangat mendasar dewasa ini adalah bahwa citra umat Islam telah dikotori oleh orangorang yang mengaku-mengatasnamakan Islam, akan tetapi tidak menunjukkan ciri khas ajaran Islam, yang santun dan ramah. Jika sudah demikian, maka satu hal yang harus diingat adalah kembali pada catatan sejarah, bahwa Islam masuk ke negeri ini dengan cara damai. Para ulama menyebarkan ajaran Islam dengan akhlak yang mulia, sehingga masyarakat yang telah beragama, pun terkesima dan akhirnya memeluk Islam.

Di era digital seperti sekarang ini, dakwah menjadi semakin menantang. Kecepatan arus teknologi informasi, akan sangat membantu umat Islam dalam menyampai risalah kebenaran dan ketuhanan. Itulah sebabnya, mulai banyak media-media yang muncul dengan orientasi dakwah. Dengan 
semakin mudahnya izin untuk mendirikan penerbitan setelah 1998, semakin banyak majalah islami yang muncul ke permukaan. Ada yang membidik perempuan dan remaja, seperti majalah Nikah, Noor, Karima, ElFata, Puteri, Muslimah, Permata, dan lain sebagainya. Dakwah kontemporer mengambil bentuk pergerakan dan pendirian organisasi, kemudian pemanfaatan media cetak maupun elektronik seperti penerbitan buku, majalah, surat kabar, pembuatan film dan dakwah melalui tv serta radio, dan internet. Penyebaran dakwah dan pengenalan tokoh-tokoh juru dakwah lebih menyebar dan mendunia. Setiap tokoh memiliki web site sendiri, seperti Yusuf Qordlowi, Abdullah Bin Baz, dan masih banyak tokoh lainnya. Layanan perpustakaan on line dan buku-buku keislaman yang bersifat digital, bisa diunduh oleh siapa saja dan kapan saja semakin mempermudah bagi mereka yang ingin mempelajari Islam. Penggunaan jejaring sosial oleh individu juga sering dijadikan media untuk membagi pengetahuannya (M. Tata Taufik, 2013: 52-53).

Oleh karena itu, para da'i di era digital harus benar mampu menggunakan media sebagai sarana untuk berdakwah. Jika dilihat dari karakteristiknya, maka masyarakat digital memiliki ciri sebagai berikut:

\section{a. Mengutamakan Data dan Fakta}

Barangkali ini bertolak belakang dengan masyarakat masa lalu, di mana mereka lebih menyukai hal-hal yang bersifat mistik, seperti kemampuan linuih, kanuragan, dan daya magic. Masyarakat di era digital lebih mempercaya data dan fakta melalui bukti-bukti nyata. Contoh kasus misalnya, seorang anak yang harus putus sekolah karena harus bekerja mencari nafkah untuk memelihara orang tuanya yang sedang sakit dan beberapa adiknya. Pada awalnya tidak banyak orang yang peduli dengan keadaannya, namun ketika ia muncul di layar televisi, dengan tayangan yang dibuat dramatis, masyarakat berduyun-duyun membantunya. Atau sebuah foto kondisi seorang yang mengenaskan akibat penganiayaan yang dipajang di media sosial, awalnya tidak banyak yang mau membantunya. Namun setelah diposting, tidak sedikit orang yang berusaha membantunya. Pendek kata, asalkan fakta dan datanya lengkap, maka 
masyarakat akan bereaksi dengan cepat menyelesaikan masalah umat, bahkan secara masif.

Kelemahan umat Islam sampai saat ini adalah masalah data. Faktanya ada, tapi tidak didukung oleh data yang akurat. Sampai sejauh ini, belum ada sebuah masjid pun yang memiliki data jama'ahnya. Bagaimana mungkin dapat menjalankan dakwah dan memenejnya dengan baik, jika data saja tidak punya? Di dunia digital, data berupa angkaangka adalah mutlak diberikan, jika ingin partisipasi masyarakat terwujud. Transparansi pengelolaan dana umat, data akurat hasil penelitian/survey, lebih diutamakan dari pada hanya sekedar berbicara di atas mimbar.

b. Menyukai yang instant

$$
\text { Masyarakat digital lebih }
$$
mengutamakan efektifitas waktu, biaya dan tenaga. Untuk mengetahui sesuatu, mereka cukup dengan membuka internet. Ada kesulitan menyelesaikan masalah kehidupan, tinggal bertanya pada google, atau web lainnya yang menyediakan informasi yang dicari. Mereka tidak lagi betah berada di perpustakaan dengan buku-buku yang tebal, yang terkadang tidak ditemukan data yang dicari. Mereka cenderung mencari instant di internet, yang lebih banyak menyediakan informasi gratis.

Fenomena yang akhir-akhir ini banyak dibicarakan, misalnya Aa Gatot, Dimas Kanjeng, dan Investasi Bodong, merupakan bukti bahwa masyarakat digital memang sangat menyukai sesuatu yang instan. Ingin cepat kaya, ingin cepat mencapai tujuan, dengan tanpa harus bersusah payah. Celakanya, mereka sering kali tertipu. Dalam penelusuran media, harus diakui bahwa banyaknya pengikut Dimas Kanjeng dan Aa Gatot karena kegiatannya pernah diupload ke Youtube. Demikian juga dengan investasi bodong, cara menjaring nasabahnya umumnya dari media sosial Facebook. Media-media ini tentu saja merupakan media digital yang canggih.

Oleh karena itu, seorang da'i dituntut untuk dapat memberikan informasi yang cukup melalui media digital. Tulis-menulis, bermain peran, dan mengemas dakwah menjadi lebih menyenangkan melalui media yang tersedia, adalah tugas berat bagi para da'i untuk segera diwujudkan lebih baik lagi. 
c. Logis dan empris.

Sebagai salah satu ciri masyarakat digital, logis adalah tuntutan yang pasti di masyarakat. Ada fakta dan data, tapi harus tetap masuk akal. Masyarakat digital menguji fakta dan data dengan logika dan empirisme (pengalaman yang dapat diulang dengan hasil yang sama). Persoalannya kemudian, adalah bahwa persoalan agama adalah pengalaman individual yang setiap orang yang menjalani pasti akan berbeda. Pada dataran ini, yang terpenting adalah fakta dan datanya ada benang merah kea rah logis dan empiris. Seperti halnya pada penelitian yang marak dilakukan di Perguruan Tinggi Keagamaan Islam (PTKI), misalnya: Shalat tahajud dapat menyembuhkan kanker (Prof. M. Soleh dari UIN Sunan Ampel), Dzikir dapat menyembuhkan kanker (M. Amin Syukur dari UIN Walisongo), dan Membaca Al-Qur'an dapat mendetoksifikasi penyakit (Mustamir Pedak dari Masjid Agung Jawa Tengah), dan lain sebagainya. Kelihatannya memang tidak masuk akal, akan tetapi dalam uji empiris, apa yang disampai menjadi kenyataan.

Permasalahan yang saat ini sangat mendesak adalah buruknya citra
Islam di media massa, akibat perang opini antara umat Islam dengan umat lainnya dan golongan satu dengan lainnya. Reaksi berlebihan dengan tanggapan yang keras dari pihak-pihak tertentu yang memprovokasi, menjadikan semakin buruknya wajah Islam dewasa ini. Di sinilah pentingnya kembali ke dakwah sufistik. Para da'i hendaknya segera menyusun strategi dakwah yang santun dan mengena di masyarakat.

\section{Kesimpulan}

Melihat kondisi umat Islam yang banyak terpojokkan, akibat penggunaan media digital yang salah, maka para da'i sudah seharusnya mulai melirik salah satu media dakwah yang pernah diterapkan oleh Rasulullah SAW, yaitu korespondensi melalui media yang sama. Kemampuan menggunakan media digital menjadi mutlak dimiliki oleh para da'i masa kini. Kendatipun sudah cukup banyak para da'i yang memanfaatkan media digital sebagai media dakwah, namun masih kalah dengan musuh islam di luar sana. Hal ini masih ditambah dengan aksi dakwah media digital dari orang-orang yang 
beraliran keras, yang tidak memberikan pengayoman bagi umat, tapi jutru memperkeruh suasana. Karenanya, dakwah melalui media digital yang sufistik, menjadi sangat urgent untuk segera dikembangkan lagi. Dakwah yang santun, kreatif dan attraktif, senantiasa ditunggu oleh umat yang haus akan spiritualitas.

\section{Daftar Pustaka}

Ahmad, Athoullah. Diktat IImu Akhlak dan IImu Tasawuf (Serang: Fakultas Syari'ah IAIN Sunan Gunung Djati, 1985).

Azra, Azyumardi. Jaringan Ulama Timur Tengah dan Kepulauan NusantaraAbad XVII-XVIII (Bandung: Mizan, 1998).

Ghalab, Muhammad. Al-Tashawuf Al Muqarin ( Mesir: Maktabah AnNahdhah, t.t.).

Hafidhuddin, Didin. Dakwah Aktual (Jakarta: Gema Insani Press, 1998).

Haryanto, Joko Tri. "Perkembangan Dakwah Sufistik Perspektif Tasawuf Kontemporer", Jurnal Addin, Vol.8, No.2, Tahun 2014.

Hornby, A. S. Oxford Advanced Learner's Dictionary of Current English (Oxford: Oxford University Press, 1995).

Kurniawan, Hery D. "Sejarah Emas Muslim Indonesia", Majalah Sabili, No. 9, Th. X 2003.

Mukri, Ridwan. ESQ Kurma: Kisah Untuk Remaja (Bandung: Dar Mizan, 2009).
Nasution, Ahmad Taufik. Melejitkan SQ dengan Prinsip 99 Asmaul Husna: Merengkuh Puncak Kebahagiaan dan Kesuksesan Hidup (Jakarta: Gramedia Pustaka Utama, 2009).

Rahmad, Jalaluddin. Islam Alernatif (Mizan: Bandung, 1999).

Rofi, Sofyan. Sejarah Pendidikan Islam di Indonesia (Yogyakarta: Deepublish, 2016).

Sasono, Adi., Hafidhuddin, Didin., dan Saefuddin, A.M. Solusi Islam atas Problematika Umat: Ekonomi, Pendidikan dan Dakwah (Jakarta: Gema Insani Press, 1998).

Shihab, Alwi. Islam Sufistik: Islam Pertama dan Pengaruhnya Hingga Kini di Indonesia (Bandung: Mizan, 2001).

Siddiq, Moch. Ajaran Tarekat dan Tasawuf (Surabaya: Putra Pelajar, 2001).

Sihbudi, M. Riza. Menyandera Timur Tengah: Kebijakan AS dan Israel atas Negara-negara Muslim (Bandung: Mizan, 2007).

Taufik, M. Tata. Dakwah di Era Digital: Seri Komunikasi Islam (Kuningan: Pustaka Al-lkhlas, 2013).

Toriquddin, M. Sekularitas Tasawuf, (Malang: UIN Malang Press, 2008).

Umarie, Barmawie. Systematika Tasawuf (Solo: Siti Syamsiyah, 1966).

Uswadin, "Ancaman Moralitas di Era Digital”, Jakarta: Republika, 28 April 2013.

http://komunikasi.us.

http://lead.sabda.org.

http://www.dakwatuna.com.

http://www.dakwatuna.com.

http://www.eurekapendidikan.com. http://www.muslimoderat.com. 
http://www.nusudan.com.

https://id.wikipedia.org .

https://www.chanelmuslim.com.

www.sufinews.com. 